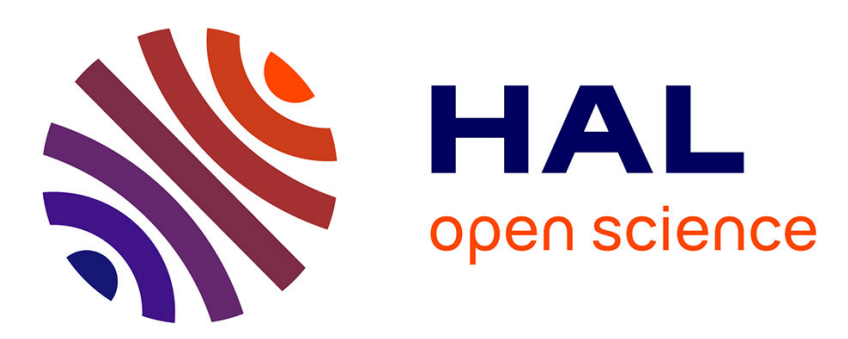

\title{
Transitioning strategies of economic survival: Romanian migration during the transition process
}

\author{
Swanie Potot
}

\section{To cite this version:}

Swanie Potot. Transitioning strategies of economic survival: Romanian migration during the transition process. Richard Black; Godfried Engbersen; Marek Okolski; Cristina Pantiru. A continent moving west? EU enlargement and labour migration from Central and Eastern Europe, Amsterdam University Press, pp.249-270, 2010, IMISCOE Research, 9089641564. hal-01318074

\section{HAL Id: hal-01318074 https://hal.science/hal-01318074}

Submitted on 19 May 2016

HAL is a multi-disciplinary open access archive for the deposit and dissemination of scientific research documents, whether they are published or not. The documents may come from teaching and research institutions in France or abroad, or from public or private research centers.
L'archive ouverte pluridisciplinaire HAL, est destinée au dépôt et à la diffusion de documents scientifiques de niveau recherche, publiés ou non, émanant des établissements d'enseignement et de recherche français ou étrangers, des laboratoires publics ou privés. 
Transitioning strategies of economic survival: Romanian migration during the transition process (1ère version auteur)

Paru dans Richard Black; Marek Okolski, Godfried Engbersen and Cristina Pantiru, $A$ Continent moving West?, AUP-IMISCOE Press, 2010, pp.249-270.

Please do not cite without permission

\author{
Swanie Potot \\ CNRS fellow researcher \\ Research Unit on Migrations and Society \\ URMIS (UMR-7032) \\ E-mail: potot@unice.fr \\ Tel: +33 (0)6-82-42-50-84/ +33 (0)4-92-00-11-89
}

\begin{abstract}
:
Drawing on qualitative fieldwork conducted between 1998 and 2003 on Romanian economic migrants, this paper proposes an analysis of the role of temporary migration within the transition process in Romania.

This article first addresses the national context from which these migrations emerged, considering the hypothesis that this transnational activity is merely a new form of the numerous survival strategies used by Romanians to resist to the economic depression which has ensued since the 1989 Revolution. Furthermore, we postulate that these new economic strategies are the prolongation and modernization of informal activities developed during communist times.

We suggest, in a second section, that migrations may play in favour of the transition process. Although Romanian migrations have long been considered a problem in terms of the process of EU accession, Romanian migrants participate in many ways in the economic restructuring of their homeland. We shall show that by investing remittances in Romania and developing transnational culture and networks, they actually accelerate the transformations of the country toward European lifestyles and standards.
\end{abstract}


Article:

\section{INTRODUCTION}

Whereas economic migrations from poorer countries are, in the West, always treated with a certain degree of misgivings, in the departure regions they are often viewed as a valuable resource, a means to opening new horizons for populations of uncertain future. The present article deals with temporary Romanian migrations toward Western Europe, focusing in particular on understanding their causes and effects in the departure country.

The study draws on several years of qualitative fieldwork conducted with Romanian migrants both within their home regions and during their stays in France (Paris, Nice), Spain (Almería province) and Great Britain (London). The study concentrates on two particular groups, the first of which is composed of relatively young adults, between eighteen and thirty, from a mid-sized city of Romania, Târgoviste, near Bucarest. These individuals first migrated to Nice, France between 1998 and 2000 as tourists, but whose stays occasionally turned into irregular stays or asylum requests. The principal occupation of these migrants entailed employment as street newspaper vendors, work aimed at helping indigent unemployed people. Although some of these migrants settled in France for several years, the more common migratory schema consisted of short stays of a few months, renewed rather regularly but always interrupted by long periods (at least six months) in the home city.

At the end of 1999, this practice noticeably changed when newspaper agencies, under pressure from public authorities, increasingly refused to employ foreigners without a work permit. London, where unskilled work abounds and where the black market is relatively tolerated, has thus progressively become the principal destination for these migrants. As salaries in London's construction and hotel sectors are substantially higher than what could be expected in southern Europe, and as the public authorities appear less likely to expel foreigners having entered illegally, London has become a particularly popular destination.

In parallel, a second series of surveys was conducted with a migratory network connecting a rural county of the Danube plain with Almería province in Andalusia where there is a high demand for unqualified agricultural work. The social profile of these migrants is different from the first group studied in that they are of diverse age groups, are less often qualified and are more often from small cities or villages. However, both migrant categories resemble each other in their frequent travels between Romania and Western Europe, movements which are oriented and reinforced by the increasing number of individual experiences and which enable the migrants to raise their own standard of living as well as that of family members in their home country. The numbers illustrate a phenomenon of great amplitude in Romania: 35 per cent of Romanian households between 1990 and 2000 counted at least one member involved in these migrations (Sandu 2000).

Throughout interviews with these migrants, it becomes apparent that the objective is not to flee Romania in order to build a new life elsewhere, but rather to temporarily compensate for the deficiencies of a faulty social and economic system (Morokvasic 1999). The migration thus becomes a way of life that involves alternating between a relatively comfortable home and an undefined elsewhere.

This article first addresses the national context from which these migrations emerge. The analysis suggests that this transnational activity is merely a new form of the numerous survival strategies used by Romanians to counter the economic depression which has ensued since the 1989 Revolution. Furthermore, we postulate that these new economic strategies are the prolongation and modernization of informal activities developed during communist times.

We suggest in a second section that migrations, although they emerged from a destabilizing context, may play in favour of the transition process. Even though Romanian migrations have long been considered a problem in terms of the process toward EU accession, 
Romanian migrants contribute in many ways to the economic re-structuring of their homeland. We shall show that by investing remittances in Romania and developing transnational culture and networks, they actually accelerate the transformations of the country toward European lifestyles and standards.

\section{POST-COMMUNIST ROMANIA AND SURVIVAL STRATEGIES}

\subsection{ROMANIA: AN ECONOMY IN TRANSITION}

December 1989 marks for the Romanian people the end of one of the most authoritarian regimes of the communist system. The 'Revolution' is also remembered, however, as the event that marks the beginning of the socio-economic crisis engendered by the transition process. In the first years following these events, the recession seemed a natural phase in the course of events. Social difficulties induced by the adoption of the market economy, once surpassed, were expected to be compensated by the growth and development of consumer society. Yet neither economic reforms in the form of aid from international institutions, such as the International Monetary Fund or the World Bank, nor political reforms ever truly led to this phase. Only in 2004 did the EU finally characterise Romania's market economy as 'viable'. During the first ten years of the transition, the recession was constant; only at the turn of the millennium was the country renewed by positive GDP growth. In 2000, the day to day difficulties even led some Romanians to the conclusion that, regardless of the dictatorship, 'things were better before' ${ }^{1}$. They have thus turned their efforts toward the satisfaction of personal needs. Although the situation has noticeably improved over the last five years, the average monthly salary remained under $295 €$ in 2007 and many households are still unable to meet their minimum needs. Nonetheless, living conditions are still difficult today and inflation, although having descended from 15.3 per cent in 2003 to 5.7 per cent in 2007 , still limits the purchasing power of the middle class. The country's dreams of rapid westernization slowly gave way to basic material concerns. The principal objective during the last ten years has therefore been, for many Romanians, to maintain their family's standard of living.

The informal economy, already flourishing under the communist regime, consequentially became all the more developed. As observed D. Kideckel, informal transactions were already commonplace at the time of Ceausescu (1993), allowing one to compensate for the deficiencies of the formal economy and to maintain a minimal standard of living. The amplitude of the parallel economy today can be understood as an extension of these earlier practices. Under communism, the informal economy primarily took the form of non-commercial exchanges and the trafficking of everyday consumer products. With the advent of capitalism, these transactions diversified and spread to new sectors. In 2002, Rainer estimated that the informal sector concerned two thirds of Romanian households (2002).

The unemployment rate, rarely surpassing 11 per cent between 1989 and 2000 and reaching a record low of 5.9 per cent in 2007, does not explain this boom in the informal economy. Whereas during the dictatorship the informal economy was attributed to a lack of products on the legal market, it is today attributed to the organisational flaws of the official system. The administrative disarray and the unreliable legal structure that followed the regime change $^{2}$ have encouraged resorting to the parallel economy. Given the complexity of the administrative procedures and the degree of corruption within the public services, business on

\footnotetext{
${ }^{1}$ The standard of living in 2000 represented only 80 per cent of its material value in 1989. Cf. (Lhomel 2001).

${ }^{2} C f$. the numerous EU reports on this subject: http://ec.europa.eu/enlargement.
} 
the black market has become easier and less costly. This alternative allows individuals to circumvent the structural hurdles in a corrupt and disorganised administration. Since the average salary, around 295 Euros (November 2007), does not provide a decent living, the informal economy also allows for ends to be met. The parallel economy is therefore in no way the privilege of a corrupt or marginal few, but rather is a common strategy throughout all of Romanian society (Rainer 2002).

The parallel economy subsists in several domains which shall be outlined in order to clarify the link between this sector and transnational migrations. G. Duchêne offers a global definition of informal activities, which 'can be defined as the ensemble of legal and illegal economic activities undertaken by small-scale (family or individual) units which generate production in the sense of the National Accounts System and which operate on the margins of the regulated socio-fiscal systems enforced by the State' (1999:36). In what follows, an abridged typology is sketched of the principal informal activities in Romania, according to the level of involvement required.

Some sections of the informal economy develop on the margins of formal economic institutions. The agricultural sector is unique in that the sales at the rural market are only rarely declared, thus situating this sector within the informal economy (Duchêne, Albu \& Kim 2002). Other small-scale businesses are more ambiguous, however. Professions such as mechanic, tailor, painter or teacher are all partially or totally beyond State control. Such work therefore falls within the black market, which represents either the individual's principal activity (primary source of revenue) or a complementary activity to salaried work or unemployment. Recourse to this form of second economic activity does not pertain to any one specific social category, but rather is commonplace throughout the working population.

Trade, generally the sector referenced when referring to 'trafficking', also appears as a major component of the parallel economy. Although the majority of this market consists of products that are not illegal to sell, the conditions of commercialisation, however, often are illegal. This can involve, notably, merchandise procured illegally from large businesses for resale on a small scale. This trafficking related to theft from State companies, frequent under communism, is now undertaken in the same fashion, although undoubtedly in smaller proportions. A second form of illegal trade consists of legally purchasing merchandise from the manufacturer and selling it as retail or to other intermediaries, avoiding State tax and control.

On top of these black market transactions are numerous other exchanges which are outside of the monetary system, relying on reciprocity. As such, the trade of vegetable conserves from the numerous small private gardens is as frequent as the traffic of influence, or 'influence peddling'. For instance, an individual can request that a civil servant relative intercede in order to accelerate an administrative procedure, receiving, in exchange, untaxed petrol from the indebted individual, whose brother works at a petrol station. Present in nearly every aspect of domestic life, the parallel economy is not limited to minor transactions. The entrepreneur who built the house of one individual, for example, was paid entirely in bottles of Tsuica, a highly demanded homemade alcohol made from plums. Beyond the ability to negotiate face to face (Péraldi 2001), these exchanges require the social actors to place themselves within an extended network of relations where each is both debtor and creditor toward the others. In addition, being rarely direct or immediate, this mode of functioning requires that individuals be implicated both daily and in the long term. Such reciprocation therefore involves a sociality that relies on and maintains close relations of confidence, all the while placing social actors in situations of perpetual interdependence. Even if partially avoiding the monetary system, this subsistence economy necessitates substantial investment of time and relations. It also enables households whose official revenue places them below the poverty threshold to not only provide for themselves, but to live in decent conditions. This 
system of reciprocity nonetheless extends beyond the lower social classes, involving the entire population.

Another type of trade, directly tied to the mobility of individuals, took on new dimensions when European borders opened. The 'suitcase trade' entails small-scale undeclared import and export that, although extremely risky during the dictatorship, has since 1990 become widespread with bordering countries, in particular Turkey, Hungary and Serbia (Aktar \& Ôgelman 1994). These small business ventures are composed of individuals acting either alone or in partnerships of rarely more than two or three who collaborate to divide the tasks. The objective is to sell in Romania products that were individually acquired on foreign markets. Audio cassettes or clothing from Istanbul are well-known examples. The comings and goings are generally by bus or train and the stays abroad are no more than a day or two. At the crossroads of transnational migrations and local trade, this business takes advantage of the international setting to minimise the effects of the unfavourable economic circumstances.

\subsection{TRANSNATIONAL MIGRATIONS AS ALTERNATIVE}

Keeping in mind this socio-economic context, the meaning of 'transnational migrations' shall first be rapidly clarified. According to B. Badie, 'reflecting on transnational networks (...) consists of analysing the construction of the social relations that bring reality and life to globalisation' (1995:16). Short of aligning with the concept of A. Portes which considers that migrations appear on the margins of the global economy, or in response to the latter (Portes 1997), we shall consider here that migrations participate in the same processes of social and economic exchanges, which increasingly exceed the limits drawn by national borders. As highlights B. Badie, the power of States on an international level is tending to lose some of its hegemony in favour of greater leeway for the strategies of autonomous social actors. The social networks they establish are increasingly spreading across multiple poles, whether through multinational companies or through 'globalization by below', to borrow the term from A. Portes related to transnational migrant communities. This does not suggest, however, that borders or spatial, social and economic disparities no longer play an important role for the migrants.

On the contrary, as we shall develop, transnational migration relies on the specific capacity of certain social actors to interrelate dissimilar localities, crossing from one to the other. The migratory networks thus create a 'transnational social field' (Glick-Schiller \& Levitt 2007) that links different places of passage, situated 'neither here nor there, but here and there at the same time' (Tarrius 1993). The fact of simultaneously belonging to different and dissociated localities is indeed what renders these migrants' situation advantageous. Such advantages are not drawn uniquely from the differences in wealth, highlighted by Piore and observed in the presented cases, which allow for meagre salaries earned in the West to be spent in Romania at multiplied value (Piore 1986). The advantages are also drawn from the increased social distance which also makes the migration worth the sacrifice, in that the degraded social status endured abroad has no impact on the experiences in the home society.

The application of the term 'transnational' not only refers to the geographic dimension which engenders the increased autonomy, but also calls attention to the spaces of sociality which underlie these movements. These spaces are characterized by 'a horizontality of social relations [which], scarcely institutionalised (...), are constituted within informal sphere' (1995:22). Apart from dependency on State power, there is in fact no pre-established hierarchy. The social relations, less codified than in the institutional structures, are constantly susceptible to evolving and even, at times, to reversing the power relations over time. Within these networks, as in the transactions which connect them to the societies they cross, the negotiations and the interpersonal relations have utmost importance, much more than that of 
any strict regulations. Thus, to speak of transnational Romanian migrations is to refer as much to the practices of circulatory mobility, these continual movements between the home city and various migratory poles in the European space, as to the forms of organisation and structuring of social relations that underlie this mobility (Potot 2008, to be published).

In Romania, these migrations must be understood as the multiplicity of individual strategies that are developed in view of minimising the deterioration of their conditions. As writes M.Morokvasic, they 'concern people who are reacting to a crisis situation by hitting the road, in order to avoid being left behind in societies engaged in a rapid and particularly unpredictable process of transformation' (1995:119). Searching elsewhere for the means to live better at home is the principal guide to these practices. For D. Sandu, the temporary business trips toward richer countries are associated with an older habit of 'shuttling' between city and countryside (1999). This 'shuttling', known in Romania as navetism, once enabled the inhabitants of rural zones to improve their living conditions by commuting to work in the city, without entirely entering the urban economic circuit. The latter, further removed from the sources of alimentary production than the rural economic circuit, was more dependent during the dictatorship. The parallel with current international mobility is clear in that the objective still consists of extending one's activities to a new territory without socially or economically breaking from the former.

In this way, transnational movements do not disrupt the local equilibrium, but rather represent a specific form of adaptation to a crisis. It is in this way that Romanians interpret their temporary migrations, more as an alternative to the local bartering system than as a way to definitively escape the Romanian condition. This continuity allowed the idea of 'Doing a season' in the West to become so popular (Diminescu \& Lagrave 1999). According to the Public Opinion Barometer, 12 per cent of the Romanian population in 2007 considered their principal preoccupation to be leaving to work abroad (Fondatia Soros Romania 2007). The act of migrating, for a portion of Romanians, is an option that requires somewhat more investment than the usual 'trafficking' but which, in exchange, promises greater profit. Similarly, the legal restrictions imposed upon border-crossing appear more as challenges to surmount than as actual barriers to migration. Romania, until the first of January 2002, was in fact subject to a specific migratory system in Europe. Until then the European Union, through the Schengen Space, closed its borders to Romanian citizens, who were forced to obtain sparingly delivered visas for the sole purpose of tourist stays. Even with the 2002 authorisation to circulate and later with the 2007 integration into the European Union, several European countries continue to protect their labour markets, so well that labour migrations to the West are often still considered illegal practices.

\subsection{DIVERSIFIED MIGRATORY PRACTICES}

In order to situate the case study which follows, a rapid chronological panorama shall be sketched of these migrations since $1989^{3}$.

Firstly, movements intensified toward the bordering countries at the beginning of the 1990s, when seasonal labour migrations toward Hungary, Yugoslavia and Turkey (which is not a bordering country but with which the exchanges are plentiful) multiplied. Having already established ties with these regions, the border populations of Romania primarily embarked on these movements, generally on the periphery of business trips.

As of 1993-94, the departures toward countries that were more distant and more difficult to access became increasingly widespread. Two types of migrations were juxtaposed. On one hand, several countries, Germany and Israel in particular, recruited Romanian labour.

\footnotetext{
${ }^{3}$ This section relies on several articles from the collective publication edited by D.Diminescu, Visible mais peu nombreux, 2003.
} 
In the framework of the Werkertrage agreements, German firms signed contracts with Romanian firms which provided not only the workers but also the materials needed for certain construction sites. Particularly popular between 1993 and 1996, these exchanges have now practically disappeared. In Israel, authorities each year decide upon a quota of guest workers per nationality. Romanians, who represented 29 per cent of the legal foreign workers in 2000, constituted the most represented national group ${ }^{4}$. These recruitments always go through local Romanian agencies which serve as intermediaries between the candidates for departure and the foreign private employers (Ellman \& Laacher 2003). Financed either by the recruitment agency or by the company itself, the latter generally commits to lodging the workers on site. Concretely, this means the possibility to obtain, from Romania, a temporary contract for migration in which everything is included and the migrant is taken care of. The advantage is clear for individuals with no experience living abroad. The enormous attraction of these recruitments inspired a great deal of trafficking. Despite being remunerated by the foreign companies, the Romanian agencies in charge of recruitment systematically sold the contracts to the workers. As the number of contracts was limited, the agencies were able to increase the cost of the work contracts on the black market. Some contracts could thus be sold for up to 2500 dollars, whereas the monthly salary guaranteed by the contract only amounted to around 1000 dollars. When this type of opportunity was first presented, circulatory migrations were at their beginnings, which meant that the migratory networks that would later facilitate temporary migrations were not yet in place. As the departure consequentially still appeared as a relatively risky adventure, in that its costs could outweigh its profits, the contracts offered the assurance of being housed and travelling economically.

Since 1995, these temporary migrations under contract have begun to serve more independent initiatives. Some contractual workers abroad maximise their revenue by accumulating jobs. In addition to the work for which they were employed, they consecrate their evenings or days off to undeclared second jobs. The value of the official contracts for the Romanian public is therefore directly related to the control exerted over the labourers' free time. Housing that is located at the construction site itself, for example, is in low demand, due to the difficulties that this represents to circumvent the employers' supervision. These contracts can also serve as passports for more independent migrants. After having made the trip with the company and perhaps having worked some time for the official employer, some migrants leave for more generous propositions nearby. Indeed, the salaries of 'imported workers' are always rather low, reduced all the more by the withholdings that supposedly compensate for food and/or board. Once in the country, the migrants can easily find more advantageous conditions on the national labour market. As such, the initial contract presents two manifest advantages: first, the migrant can take the time to appraise his place of work and analyse other employment options while assured work. Some migrant maintains this initial employment for several months before moving on. Furthermore, the recruitment attributes the right to stay legally in the country until the end of the contract. However, as notes the Israeli Central Bureau of Statistics, the workers often do not immediately return to their home countries at the end of these contracts (Ellman \& Laacher 2003). Familiar with the area after several months working legally at the initial site of employment, they may consider staying on illegally for some time in the country.

This partially accounts for the fact that the primarily illegal individual migrations first appeared alongside the legally organised migrations. Migrants bound by no contract followed in the footsteps of those who were, at least initially, contractual. The preferred destination of illegal movements was, as of 1993-94, Germany. Migrants having procured contracts there

\footnotetext{
${ }^{4}$ These statistics, published in The Internet Jerusalem Post on 30 October 2001, do not take account of
} Palestinian workers whose status is particular. 
often served as relays for their independent compatriots. Even without giving any real assistance on site, they were the initial link between the homeland and the host destination. Having conveyed information to their families and friends about their experience abroad, they implicitly encouraged voyages to these regions. Likewise, the Aussiedler ${ }^{5}$, recently emigrated from Romania, created ties between certain regions of Germany and their departure region in Transylvania (Michalon 2003), prompting the first independent migrants to follow the same paths. In this way the legally framed migrations have oriented the undocumented migrations since their outset.

These migrations later expanded to other European countries, facilitated by the very concept of the Schengen Space. The convention that binds the signatory countries ${ }^{6}$ stipulated the elimination of the control of people, regardless of their nationality, at the interior borders through the harmonisation of custom controls at the exterior borders and the development of homogeneous visa policies. As a result, after crossing the first border, the migrants are no longer hindered in travel between one country and another. It has since been possible for them to explore different countries in the aim of identifying the particularly attractive destinations. Thus when Germany increased its labour controls as of 1997, restricting black market labour, or when France limited the requests for asylum in $1998^{7}$, reducing the opportunities to remain legally in its territory, the migrants simply left these countries for other European destinations. As of 1995, Italy's relatively permissive policies also attracted many temporary Romanian workers, followed by Spain and later the United Kingdom

The range of destinations was once again modified with the integration of certain countries into the European Union in 2007 and the subsequent opening of their labour markets ${ }^{8}$, although this does not seem to have amplified or reduced the phenomenon. In fact, according to the statistics of the Public Opinion Barometer, 18 per cent of the population in 2000 hoped to work abroad temporarily, against 12 per cent in 2007 (Fondatia-SorosRomania 2007).

The choice of a migratory destination depends on several factors. The most important is undoubtedly the profitability of the migration. In other words, it is indispensable for the migrants to have the possibility to work upon arrival. Their arrival must therefore coincide with labour potential in the host country's labour market. In the South of Spain, for instance, a substantial 'pull factor' in the local agricultural sector has attracted a high number of Romanian migrants. Undocumented immigration in this region has been greatly utilised by this sector over the last twelve years. Thanks to low salaries offered to this workforce that lacks legal rights, this sector has been able to reduce its production costs and place first in Europe for the sale of fresh produce. Besides domestic work, which employs a portion of the women, undocumented Romanians have no other employment opportunities in the province of Almería. Their arrival in this region is thus clearly correlated to the opportunities offered by the agricultural sector.

\footnotetext{
${ }^{5}$ The concept of Aussiedler, as defined by the 1953 law on refugees and displaced persons (Bundesvertriebenen -und Flüchtlingsgesetz), designates in Germany the immigrants of German minorities, from central or oriental Europe or the former URSS, whose German nationality is recognized.

${ }^{6}$ The countries having signed the Schengen Convention that constitute the 'Schengen Space' include: Germany, Austria, Belgium, Denmark, Spain, Finland, France, Greece, Italy, Luxembourg, the Netherlands, Portugal, Sweden and, although not part of the European Union, Norway and Iceland.

${ }^{7}$ In accordance with the law called Loi Chevènement of 11 June 1998, requests for asylum from Romanian citizens are urgently processed, in less than ten days, and almost systematically refused.

${ }^{8}$ Since 2007, ten EU-25 Member States (Czech Republic, Estonia, Cyprus, Latvia, Lithuania, Poland, Slovenia, Slovakia, Finland and Sweden) have liberalised through national law the access to their labour markets for Romanian workers. In Finland, Cyprus and Slovenia, employment must subsequently be registered for monitoring purposes. The remaining EU-25 Member States have maintained work permit systems, albeit sometimes with modified and simplified procedures.
} 
Similarly, migrants encountered in London were working principally in the construction, hotel and catering industries, in positions generally reserved for foreigners. Repression of illegal labour being minimal in the United Kingdom, these migrants have no difficulty being employed alongside lawful co-workers. Notwithstanding, Romanians are able to find their place in these particular sectors of London for the simple reason that these sectors are open to foreign populations.

The case observed in the French Riviera illustrates the implicit course of action presiding over the migrants' paths. For four years the migrants of Târgoviste were street vendors for a newspaper in Nice. This activity allowed them not only to meet their needs on site, but also to put aside savings for their return. Although black market labour in construction sometimes complemented this income, the Romanians were not able to obtain full-time employment due to the lack of positions. It was thus the initial activity that assured the success of the migration. As of 1997, the popularity of street newspaper sales in France began to decline. Then in 1998, in order to restore its image, the publishing company in Nice terminated employment of undocumented migrants among its vendors, consequently ending the principal occupation of the Romanian population studied. The outcome within the migrant network was immediate; Nice was abandoned in favour of regions such as Milan and London which promised other opportunities.

A second essential factor in choosing a migratory destination concerns the collective knowledge of the location. Only the most informed migrants dare to conquer new territories. The majority take the positions already tested by the network they are affiliated with, in locations where they already have friends who have provided useful information. The migrant is thus bound to the collective memory of the group, which is utilised to orient his/her actions. Each experience enriches the stock of shared knowledge, orienting new migrants in the same direction. The migrants therefore branch out into niches (Waldinger 1994) throughout the European space, inhabiting some territories and leaving others.

Another important element in the choice of destination includes the relations of the local authorities with the undocumented migrants. As being expelled to one's country before having collected sufficient savings constitutes a failure, migrants seek destinations that present the least possible amount of risk. For undocumented migrants ${ }^{9}$, who constitute the majority of independent migrants ${ }^{10}$, the way that laws are applied is more important than the legislation. Some countries, including France, Germany or Austria, are particularly uncompromising toward illegal migrants, while others, where the economies make massive use of undeclared labour, are more indulgent. The study conducted in Almeria provides a good example of the informal management of undocumented migration. In this agricultural province, the migrants are not stopped by the police during the farming breaks, between noon and four p.m. However, foreigners are systematically monitored if they loiter in public spaces during working hours. In this way, the authorities 'sort' between migrants who fulfil the economic role expected of them, and those who attempt to leave the agricultural sector. Likewise, undocumented migrants are aware that police leniency ceases at the perimeter of the agricultural territory. Travelling in the rest of the country translates leaving the zone of leniency which characterises the province of Almería. These observations demonstrate that beyond national borders, there are enclaves in the European space which are more conducive to constituting a migratory niche.

\footnotetext{
${ }^{9}$ Even before the end of the visa system, the majority of Romanians travelled abroad with a legitimate tourist visa for the Schengen space. However, the interdiction to procure salaried work and the limitation of stays to a period of less than three months rendered these migrants undocumented in the countries where employed.

${ }^{10}$ As opposed to those who are recruited by contract from Romania.
} 


\section{THE MIGRANTS DURING THE TRANSITION PROCESS}

Although the migrations are closely linked to the socio-economic situation of post-communist Romania, it is necessary to observe how they contribute to the current development of the country. The aim here is not to evaluate the economic contributions of the migrations, but rather to use concrete observations to indicate the different aspects of local socio-economic life which are noticeably impacted by migratory activity. Three principal means can be observed through which the migrants, in bridging their city of origin with the Occidental locations, transform Romanian lifestyle. To begin with, their activity generates new lifestyles for themselves and new attitudes toward consumption in Romania. Secondly, the formation of a social group identified by migration and social ascension fosters some level of racketeering among the middle classes, which encourages the creation of small businesses in the departure regions. Lastly, these transnational skills can be put to the service of other social actors in order to facilitate trade and, above all, to support the implantation of foreign companies in Romania.

\subsection{A NEW CONSUMERIST MODEL}

To understand how migrations have transformed the modes of consumption in Romania, we must first briefly return to the economy of Romanian households and individuals. In the words of the latter, the transition from one political system to another can be summarised as follows: 'Before we had money but the stores were empty. Today the stores are full but we no longer have the means to buy the bare minimum, ${ }^{11}$. Indeed, although the average monthly salary after tax in 2007 was only around 295 Euros, the prices of commercial products are only slightly lower than those in Occident. This situation leads the majority of Romanian households to employ strategies in order to meet their daily needs. The informal economy which once served to compensate for supply shortages in the official market is therefore today a precious resource to compensate for the decreased buying power.

Whereas before the first departure the migrants still partake in these informal transactions, their behaviours transform upon return. In fact, they tend to denigrate the informal market, turning toward the formal consumer economy, which they perceive as typically Occidental. Everyday consumer products such as food or clothing are primarily bought in retail stores, preferably in the local subsidiaries of foreign chain stores. In the city studied, the mini-market of the Total petrol station had become the primary source of necessities for returning migrants. For them, the fifty square meters of this shop incarnated the Western European mode of consumption. Direct access to products of brightly coloured and illustrated packaging led the Romanian clients to consider the purchases in a new and amusing way. In the space of a few years, Carrefour stores became the symbol of Occidental consumerist modernity. Shopping regularly in this type of store, in spite of the considerably higher prices than at the traditional market, returning migrants show their fellow citizens to what extent the migration has transformed their lives. On one hand, it has provided the financial means to abandon the black market which is now described as the pathetic legacy of a time past; while on the other hand it has conditioned them to a different and more modern lifestyle that has been integrated into their daily lives.

The fact that these practices are part of a performance aimed at faceting the image of the migrant is of little importance here. What emerges is not only that part of the profit from the migration is reinvested in the formal economy, but that the latter has amplified value on a symbolic level. The migrants' behaviour associates the notion of social mobility with

\footnotetext{
${ }^{11}$ This remark was heard repeatedly during the interviews in Romania.
} 
consumer practices in the formal economy. Now spread beyond the migrant circle, this tendency contributes to reducing the number of informal transactions and encourages behaviour that more resembles European standards. Such trends increase the clientele of legitimate businesses, boosting their economic situation. From this standpoint, it appears that migratory movements contribute to transforming not only the perceptions of the middle classes, but also their economic behaviour.

\subsection{EMULATION OF CAPITALISM}

Although these attitudes undeniably impact consumption behaviours concerning daily needs, we cannot conclude that all of the profits from migration are reinvested in the formal economy, or that migrants have given up taking advantage of their social networks to attain certain resources. On the contrary, the migration enriches the migrants' social capital (Bourdieu 1985), which is highly valuable in the home regions. This shared social status in Romania, along with the shared experience abroad, engenders a sort of social group in the departure regions. The rapid social ascension and the belonging to an extended geographical space create ties between the migrants that lead them to distinguish themselves from their fellow citizens and to rally around a common culture. The two principal markers that identify the migrant group in Romania thus concern a shared experience abroad and the collective construction of the migrant's image in the home region. Although some migrants may have helped each other out during the stays abroad, there are no observable strong feelings of belonging to the emigrated community (Potot 2007). It is really only in the country of origin that the migrants publicly demonstrate a collective identity. Groups of migrants are commonly encountered in the fashionable bars and discothèques, verbosely expressing their affection for the region of their recent migration. Many symbols are employed to express this attachment, such as using certain words in French, English or Spanish, wearing clothing of Occidental brand names or arriving in cars which, visibly parked in front of these businesses, still sport foreign plates even several months after the return to Romania ${ }^{12}$. Not only do these public demonstrations enable the migrants to boast their social ascension, but they are also useful in the world of business.

The migrants have generally put aside some savings for their return and, although one part of this will be spent in an ostentatious fashion, many will attempt to exploit this capital once in Romania. To do so, belonging to the migrant social group could prove to be useful. In fact, the migrants find that their peers have an investment capacity more or less equivalent to their own, are willing to take some financial risks, generally have partners abroad they can rely on and have a similar goal to maintain their new living standard. It is thus frequent for migrants to partake in small-scale business together. This often entails momentary business ventures, such as buying material from a factory going out of business to resell it for a profit, exporting a cut of wood to Turkey or reselling a consignment of telephones from Germany. These dynamics which encourage the spirit of enterprise also occasionally lead to the creation of more perennial business. In one example, a taxi business in Bucharest was created when one migrant's stay in France enabled him to buy a car, for which he employed a driver in order to return abroad and save enough funds to buy a second vehicle. While some of these endeavours, as in the example cited, were planned before the initial departure and represent the principal reason for the migration, others are generated from opportunities issuing directly from the experience abroad. A young man who had spent a few months in the agricultural sector of Andalusia, for example, returned to Romania in order

\footnotetext{
${ }^{12}$ Several people interviewed claimed to have bribed the police in order to keep the foreign plates beyond the legal time limit.
} 
to open an exporting business of window boxes, which he sold directly to his former Spanish employer through a compatriot who had remained there.

The migration not only provides the economic means to launch this type of business, it also develops the necessary skills such as the capacity to negotiate, to handle uncertain situations, or to make a profit from the marginal domains that are neglected by the public authorities. Likewise, Taylor reveals an indirect effect of the migrations on entrepreneurship: because they accumulate capital, the migrants can serve as a financial guarantee for friends and family (1999). In this way, even when unspent, the existence of savings to rely upon in the event of bankruptcy has encouraged risk-taking even by those not directly involved in the migration. It therefore appears clear that, even if many of these business ventures have a limited life span, the migratory movements support the development of small-scale capitalism through individual initiative in a country where the majority of the private sector emanates from foreign investments and the privatisation of large State businesses.

\subsection{TRANSNATIONAL MEDIATORS}

Finally, the migrants can be considered as strategic elements in foreign investments, as their multinational culture enables them to bridge foreign businesses or investors with Romanian society. Their skills can be put to a multitude of uses. Stocchiero highlights the role of migrants in the region of Veneto, Italy during the relocation of the Italian clothing industry to the region of Timisoara-Arad (2002). The study insists on the association which can be established between the arrival of undocumented Romanian workers in this Italian province during the nineties and the massive relocation of the clothing sector to Romania.

A qualitative approach enables clarification of the part played by the migrants. Not only are they familiar with several languages, but having lived in the originating environment of the business, they are in a position to anticipate the difficulties and expectations of the foreign entrepreneurs in Romania. They are therefore able to assist these latter to deal with the inflexible Romanian administration, as well as to negotiate with the public authorities or the eventual partners of the budding businesses. For a small-scale foreign investor, the support of a person of confidence in the host country proves to be essential. Additionally, regardless of the migrants' occupation during their stays in the European Union, the experience led them to work in an environment which contrasts with that in postcommunist businesses. Even when relegated to the least respected positions, they were obliged to conform to the Occidental working style, to accept the company rules and to demonstrate devotion often by submitting to intensive work hours or sometimes by showing initiative, etc. These tendencies are hardly natural in a country where for several decades work was mandatory, over-employment the general rule, inactivity frequent due to the lack of raw materials and the plundering of the company a normal way to compensate for the failures of the system. Still today, the expected behaviour of an employee of a large Romanian company, such as the Romanian National Railway Company, is a far cry from the concept of a young dynamic employee promoted by Carrefour or McDonald's who is at the service of the customer. Foreign businesses require that their Romanian employees adapt in some ways. Although this adaptation is encouraged by offering higher salaries than those offered by local businesses, it requires tedious efforts on-site with the employees, who are expected to integrate a work ethic that was only recently imported in Romania. The migrants, who themselves had to adapt to a work environment that they were not accustomed to during their stay abroad, are particularly competent to convey the requirements of the foreign businesses to the Romanian employees. Being familiar with the work habits in Romania, they can anticipate the difficulties that could be brought about by Occidental-style management of personnel. 
One young woman, for example, told of her one year of work in a shoe-making business in the region of Milan. When this company relocated part of its production to Romania, she was first asked to participate in the prospective phase, during which she served as interpreter then as go-between with the local administration. Later, when the factory opened, she became the personnel supervisor and the relay between the Italian directors and the Romanian workers. On top of the recruitment of new personnel, her role consisted of conveying the company's expectations to the new employees. Her two principal objectives at the time of our meeting were to end the numerous unexpected and unjustified employee absences, which greatly disturbed the production rhythm, and to avoid theft of raw materials and finished products. She attested to the difficulty of putting in place a work ethic which had seemed natural in Italy. At the same time, she was not at all surprised by these obstacles and hypothesised that if the numerous Romanian migrants were able to adapt without difficulty to the Italian business spirit, it had to be possible to 'make the Romanian mentalities evolve as well'. It is indeed this role that is expected of the migrants: that of mediator between different cultures which are increasingly similar. Turning to migrants thus allows foreign businesses, likely to have difficulty understanding the attitude of their employees, to avoid incomprehension with the latter, who are unaccustomed to satisfying such requirements at their place of work.

\section{CONCLUSION}

The aim in this text was in no way to glorify the Occidental model of society; it does not aim at judging whether or not the so-termed transition process, which is inclined to transform a country deeply rooted in communist references and to encourage a capitalistic mode of organisation, is overall positive ${ }^{13}$. Yet whereas the subject of migrations is often approached as a factor inhibiting accession to the European Union ${ }^{14}$ or otherwise as a desertion at a time when the country needs all its resources, this analysis highlights the contribution of migrants to the economic and social changes occurring in Romania. It elucidates the fact that the financial gains sent home, 'remittances' in the economic literature, are not the only contribution of the migrants to their country. Throughout their transnational movements, they acquire behaviour, knowledge and skills which are also reinvested in their home regions. In doing so, far from the projects of international cooperation or the programs of cultural exchange supported by the Ministries, the migrant networks are at the core of a pan-European culture which is progressively penetrating the countries that have only very recently joined the European Union.

\footnotetext{
${ }^{13}$ According to polls published by the Romanian press in 1999, 60 per cent of the population judged that, despite the dictatorship, 'things were better before', (Durandin 2000:10).

${ }^{14}$ The 'migratory potential' of Romania has often instigated debate in the negotiations regarding accession to the European Union. See the Internet site consecrated to European Union enlargement: http://ec.europa.eu/enlargement.
} 


\section{Bibliography}

Aktar, C. \& N. Ôgelman (1994), 'Recent Developments in East-West Migration: Turkey and the Petty Traders', International Migration 32 (2): 343-353.

Badie, B. (1995), 'Préface', in A. Colonomos (ed.), Sociologie des réseaux transnationaux, 1517. Paris: L'Harmattan.

Bourdieu, P. (1985), 'The forms of Capital', in Richardson (ed.), Handbook of Theory and Research for the Sociology of Education, 241-258. New York: Greenwood.

Colonomos, A. (ed.) (1995), Sociologie des réseaux transnationaux. Paris: L'Harmattan.

Diminescu, D. \& R.-M. Lagrave (1999), 'Faire une saison. Pour une anthropologie des migrations roumaines en France. Le cas d'Oas', Migrations Etudes 91.

Duchêne, G. (1999), 'Les revenus informels en Roumanie: estimation par enquête', Revue d'Etudes Comparatives Est-Ouest 30 (4): 35-64.

Duchêne, G., L.-L. Albu \& B.-Y. Kim (2002), 'An attempt to estimate the size of informal economy based on household behaviour modeling', Romanian Journal of Economic forecasting 1: 17-24.

Durandin, C. (2000), Roumanie: un piège? Editions Hesse, coll. Ister.

Ellman, M. \& S. Laacher (2003), Migrant workers in Israel. A contemporary form of slavery. Réseau euro-méditerranéen des droits de l'Homme (REMDH), Fédération internationale des ligues des droits de l'Homme (FIDH),48. Paris.

Fondatia-Soros-Romania (ed.) (2007), Barometrul de opinie publica. Bucurest.

Glick-Schiller, N. \& P. Levitt (2007), 'Conceptualizing simultaneity. A Transnational Social Field Perspective on Society', in A. Portes \& J. DeWind (ed.), Rethinking Migration. New Thoeretical and Empirical Perspectives, 181-218. New York: Berghahn Books.

Kideckel, D. (1993), The Solitude of Collectivism. New York: Cornel University Press. Lhomel, E. (2001), 'Roumanie 2000-2001. Un nouveau départ?' Le courrier des pays de l'Est (1016): 164-177.

Michalon, B. (2003), 'De la politique des Aussiedler à la circulation. Diversification des pratiques migratoires des Saxons de Transylvanie', in D. Diminescu (ed.), Visibles mais peu nombreux. Les circulations migratoires roumaines, 65-98. Paris: Editions de la Maison des Sciences de l'Homme.

Morokvasic, M. (1995), 'Entre l'Est et l'Ouest, des migrations pendulaires', in M. Morokvasic \& H. Rudolph (ed.), Migrants. Les nouvelles mobilités en Europe, 119-157. Paris:

L'Harmattan.

Morokvasic, M. (1999), 'La mobilité transnationale comme ressource: le cas des migrants de l'Europe de l'Est', Cultures et Conflits (33-34): 105-122.

Péraldi, M. (2001), 'Introduction', in M. Péraldi (ed.), Cabas et Containers. Activités marchandes informelles et réseaux migrants transfrontaliers, Paris: Maisonneuve et Larose, MMSH.

Piore, M. (1986), 'The Shifting Grounds for Immigration', The Annals of the American Academy: 23-33.

Portes, A. (1997), Globalization from Below: The Rise of Transnational Communities: Princeton University.

Potot, S. (2007), Vivre à l'Est, travailler à l'Ouest. Les routes roumaines de l'Europe. Paris: L'Harmattan.

Potot, S. (2008, to be published), 'Romanian circulation: networks as informal transnational organisations', in C. Bonifazi, M. Okólski, J. Schoorl \& P. Simon (ed.), International migration in Europe: new trends, new methods of analysis, Amsterdam: Amsterdam University Press - IMISCOE Series.

Rainer, N. (2002), 'Aspects of the Informal Economy in a Transforming Country: The Case of Romania', International Journal of Urban and Regional Research 26 (2): 299-322. 
Sandu, D. (1999), Spatiul social al transitiei. Bucarest: Polirom.

Sandu, D. (2000), 'Migratia circulatorie ca strategie de viata', Sociologie romaneasca (2 serie noua): 5-30.

Stocchiero, A. (2002), Migration Flow and Small and Medium Sized Enterprise

Internationalisation between Romania and the Italian Veneto Region: Centro Studi Politica

Internazionale.

Tarrius, A. (1993), 'Territoires circulatoires et espaces urbains', Annales de la Recherche Urbaine (59-60): 50-60.

Taylor, E. J. (1999), 'The New Economics of Labour Migration and the Role of Remittances in the Migration Process', International Migration 37 (1): 63-88.

Waldinger, R. D. (1994), 'The making of an immigrant niche', International Migration Review 8 (1): 3-30. 